\title{
Effect of aminoethoxyvinylglycine on biochemical, physico- mechanical and colour properties of cv. Braeburn apples
}

\section{Efeito da aminoetoxivinilglicina nas propriedades físico-mecânicas, bioquímicas e cor da maçã cv. Braeburn}

\author{
Burhan Ozturk ${ }^{1 *}$; Yakup Ozkan ${ }^{1}$; Ebubekir Altuntas ${ }^{2}$; \\ Kenan Yildiz ${ }^{1}$; Onur Saracoglu ${ }^{1}$
}

\begin{abstract}
The effect of preharvest AVG (aminoethoxyvinylglycine) treatments on the biochemical, physicomechanical properties and colour characteristics of $\mathrm{cv}$. Braeburn apples were determined. AVG was applied in four different doses $\left(0,100,300\right.$ and $\left.500 \mathrm{mgL}^{-1} \mathrm{AVG}\right) 4$ weeks before the estimated harvest date. While the lowest values of total soluble solids content and $\mathrm{pH}$ were obtained from $500 \mathrm{mgL}^{-1}$ AVG treatment, the highest values were obtained from control. The titratable acidity was higher in 500 $\mathrm{mgL}^{-1}$ AVG treatment than those of the 100 and $300 \mathrm{mgL}^{-1}$ AVG treatments. The highest total phenolic and antioxidant activity of both flesh and skin apple was obtained from control, whereas lowest value was obtained from $500 \mathrm{mgL}^{-1} \mathrm{AVG}$ treatment. With increasing doses of AVG, the total monomeric anthocyanin was reduced. The geometric means, fruit diameter, fruit mass, fruit removal force, flesh and skin firmnesses increased with increasing doses of AVG. The hue angle values of flesh and skin fruit were lower in control.
\end{abstract}

Key words: Malus domestica Borkh, colour, FRAP, phenolic compounds

\section{Resumo}

Foram determinados os efeitos do tratamento em pré-colheita com aminoetoxivinilglicina (AVG) nas propriedades bioquímicas, físico-mecânicas e características da cor da maçã 'Braeburn'. AVG foi aplicado quatro semanas antes da data estimada de colheita, em quatro doses $(0,100,300$ e $500 \mathrm{mgL}$ $\left.{ }^{1}\right)$. Enquanto os menores valores de sólidos solúveis totais e $\mathrm{pH}$ foram obtidos no tratamento com 500 $\mathrm{mgL}^{-1} \mathrm{AVG}$, os maiores valores foram obtidos no tratamento com $0 \mathrm{mgL}^{-1} \mathrm{AVG}$. A acidez titulável foi maior no tratamento com $500 \mathrm{mgL}^{-1} \mathrm{AVG}$ do que nos tratamentos $100 \mathrm{e} 300 \mathrm{mgL}^{-1}$. A maior atividade de fenólicos totais e antioxidantes na polpa e na casca da maçã foi obtida no tratamento com $0 \mathrm{mgL}^{-1} \mathrm{AVG}$, enquanto que o menor valor foi obtido no tratamento com $500 \mathrm{mgL}^{-1}$ AVG. Com o aumento das doses de AVG, a antocianina monomérica total foi reduzida. As médias geométricas diâmetro do fruto, massa do fruto, força de remoção de frutas, polpa e casca aumentaram com o aumento das doses de AVG. Os valores do ângulo da matriz de polpa e casca da fruta foram menores no tratamento com $0 \mathrm{mgL}^{-1} \mathrm{AVG}$. Palavras-chave: Malus domestica Borkh, cor, antioxidantes, compostos fenólicos

1 Doctor Prof. Department of Horticulture, Faculty of Agriculture, University of Gaziosmanpasa, 60240 Tasliciftlik, TokatTurkey. E-mail: burhanozturk55@gmail.com; yakup.ozkan@gop.edu.tr; kenan.yildiz@gop.edu.tr; saracoglu@gop.edu.tr

2 Prof. Department of Biosystems Engineering, Faculty of Agriculture, University of Gaziosmanpasa, 60240 Tasliciftlik, TokatTurkey. E-mail: ebubekir.altuntas@gop.edu.tr

Author for correspondence 


\section{Introduction}

Apples (Malus domestica Borkh.) are a significant part of the human diet (WOLFE; WU; LIU, 2003). In addition, they have been identified as one of the main dietary sources of antioxidants, mainly phenolic compounds, such as flavonoids, rather than essential vitamins, such as vitamin $C$, which explains only $0.4 \%$ of the total antioxidant activity (BOYER; LIU, 2004). Phenolic compounds are naturally occurring plant secondary metabolites which determine outer and inner quality parameters of fruits such as appearance, flavor and health-promoting properties (TREUTTER, 2001; LATTANZIO, 2003). The phenolic compounds are responsible for most of the antioxidant activity of the apple (TSAO et al., 2005). Anthocyanins are natural pigments, responsible for a wide range of colours in apple. Anthocyanins contribute greatly to the antioxidant properties of certain colourful foods, such as apple, grapes and cranberries.

Parameters such as fruit size, skin colour, flesh firmeness, soluble solids and titratable acidity are used to determine the maturity of fruit at harvest. Consumers demand excellent appearance, firmness and optimum texture of apple. Quality of apple consists of a combination of visual appearance, flavour and texture. Apple fruit ripening is a process that results in changes in fruit quality such as decreased starch, firmness and fruit removal force, increased red colour and changes in anthocyanin, total phenolic content and total antioxidant activity (MARI et al., 2010).

The biochemical (TSS, $\mathrm{pH}$, phenolic, antioxidant and anthocyanin), physico-mechanical (size, shape, skin thickness and firmness and fruit removal force) and colour properties in fruits have changed by several factors. Particularly, these compounds have changed with cultivars preferred, fruit maturity, light exposure, growth period, growing area, environmental conditions, organic or non-organic production, harvest period, post-harvest factors, storage and processing and other cultural factors
(STURM et al., 2003; LATA, 2007). Growth regulatory substances have been evaluated among factors causing changes in these parameters (FAN et al., 1997).

AVG (aminoethoxyvinylglycine) has been widely used in apple and improved the quality of fruit. And also, AVG treatment has been delayed fruit maturity and decreased the preharvest fruit drop by inhibiting ethylene that cause to accelerate the maturation at period before harvest (BRAMLAGE et al., 1980). In addition, the control of vegetative growth and regulation of flowering (BANGERTH, 1978), size, shape, colour development and postharvest quality (WILLIAMS, 1980; WANG; DILLEY, 2001) have been manipulated with using of AVG.

The aim of this study was to determine the effects of AVG plant growth regulator on biochemical (total phenolic, total antioxidant activity, total monomeric anthocyanin, total soluble solids content, $\mathrm{pH}$, titratable acidity, and starch index), physicomechanical properties (geometric mean diameter, skin and flesh firmnesses and fruit removal force), and colour characteristics of apple.

\section{Materials and Methods}

\section{Site and climatic conditions}

The plant material of the research was obtained from the Research and Application Orchard of Agricultural Faculty of Tokat (39.51' $\mathrm{N}$ and $40^{\circ} 55^{\prime}$ E) Gaziosmanpaşa University, situated in the Middle Black Sea Region in Turkey, in 2010. According to average rainfall values for the past decades in the region, the annual lowest and highest average temperatures, relative humidity and rainfall are $8.1-14.2^{\circ} \mathrm{C}, 56-73 \%$, and $381.8-586.2 \mathrm{~mm}$, respectively (ANONYMOUS, 2011).

\section{Plant material}

The cv. Braeburn apple tree (Malus domestica Borkh.) grafted on MM106 rootstock was planted 
on the land in a $3.5 \mathrm{~m}$ apart in the row and $2 \mathrm{~m}$ between rows order $(3.5 \times 2)$ in 2006 . The trees used in the experiment were trained according to the modified-leader system. The trees selected for the experiment had homogeneous fruit load.

\section{Treatments}

All treatments were arranged in a randomized complete block design with three replications. In the study, the AVG, aminoethoxyvinylglycine (ReTain ${ }^{\circledR}$, 15\% a.i., Valent BioSciences Corp., Libertyville, III) was applied in four different doses [0 (AVG0), 100 (AVG-1), 300 (AVG-2) and $500 \mathrm{mgL}^{-1}$ (AVG-3)] four weeks before the estimated harvest date (September 18, 2010). The solutions contained 0.05\% Sylgard-309 organosilicone surfactant (Dow Corning chemical, Istanbul, Turkey) to prevent runoff was added to the solutions. The control trees were sprayed only with water $(\mathrm{pH}=6.48)+$ surfactant. The apples were randomly hand-picked. Studied apple fruits harvested on October 16, 2010 and they were transferred to the laboratory in polyhthene bags to reduce water loss during transportation.

\section{Measurements}

\section{Biochemical properties}

In order to determine the quality properties of the fruit, 25 fruits from every replication were harvested. After assessment of fruit firmness, fruit juice was extracted by homogenising fruit flesh in a blender, TSS (total soluble solids content) of the juice was measured with a digital refractometer (PAL-1, McCormick Fruit Tech., Yakima, Wash.) and expressed as percentage. The $\mathrm{pH}$ of apple fruit was measured by $\mathrm{pH}$ meter (Hanna, model HI9321).

The titratable acidity ( $\mathrm{g}$ malic acid $100 \mathrm{~g}^{-1}$ ) was determined using five fruit from each sample (20 pieces of fruit in total) by titrating $10 \mathrm{~mL}$ of juice with $\mathrm{NaOH} 0.1 \mathrm{~N}$ up to $\mathrm{pH} 8.2$ and expressed as percentage of malic acid.
The starch index was assessed using the Cornell University, Generic Starch-Iodine Index Chart. Each apple fruit was cut in half transversely, and then flesh starch was evaluated by spraying half of each apple in iodine solution for $\approx 30 \mathrm{~s}$. The degree of staining was rated on scale of 1 to 8 , in which $1=$ staining of entire cut surface and $8=$ absence of staining (BLANPIED; SILSBY, 1992).

Total phenolics (TP) was measured according to the Singleton and Rossi (1965) procedure. Briefly, fruit slurries were extracted with buffer containing acetone, water, and acetic acid (70:29.5:0.5 v/v) for 2 h. in darkness. Samples were replicated three times. Extracts were combined with Folin-Ciocalteus phenol reagent and water, and incubated for $8 \mathrm{~min}$ followed by the addition of 7\% sodium carbonate. After $2 \mathrm{~h}$, the absorbance at $750 \mathrm{~nm}$ was measured in an automated UV-VIS spectrophotometer (Model T60U, PG Instruments, USA). Gallic acid was used as the standard. The results were expressed as $\mathrm{mg}$ gallic acid equivalents (GAE)/kg fw.

Total antioxidant activity (TAA) was estimated using two standard procedures, the FRAP (Ferric reducing antioxidant power) and TEAC (Trolox equivalent antioxidant capacity) assays, as suggested by Ozgen et al. (2006). FRAP was determined according to the method of Benzie and Strain (1996). The assay was conducted using three aqueous stock solutions containing $0.1 \mathrm{~mol} / \mathrm{L}$ acetate buffer ( $\mathrm{pH}$ 3.6), $10 \mathrm{mmol} / \mathrm{L}$ TPTZ [2,4,6-tris(2pyridyl)-1,3,5-triazine] acidified with concentrated hydrochloric acid, and $20 \mathrm{mmol} / \mathrm{L}$ ferric chloride. These solutions were prepared and stored in the dark under refrigeration. Stock solutions were combined $(10: 1: 1 \mathrm{v} / \mathrm{v} / \mathrm{v})$ to form the FRAP reagent just prior to the analysis. For each assay, duplicates of each replicate plus $2.90 \mathrm{~mL}$ of FRAP reagent and $100 \mu \mathrm{L}$ of sample extract were mixed. After $30 \mathrm{~min}$. the absorbance of the reaction mixture at $593 \mathrm{~nm}$ was determined on a spectrophotometer. The results were expressed in mmol Trolox equivalent (TE)/ $\mathrm{kg}$ fw. For the standard TEAC assay, $10 \mathrm{mmol} / \mathrm{L}$ 
ABTS (2,2-azino-bis-3-ethylbenzothiazoline-6sulfonic acid) was dissolved in acetate buffer and prepared with potassium persulfate as described in Ozgen et al. (2006). The mixture was diluted using an acidic medium of $20 \mathrm{mM}$ sodium acetate buffer (pH 4.5) to an absorbance of $0.700 \pm 0.01$ at $734 \mathrm{~nm}$ for longer stability (OZGEN et al., 2006). For the spectrophotometric assay, $2.90 \mathrm{~mL}$ of the $\mathrm{ABTS}^{+}$ solution and $100 \mu \mathrm{L}$ of fruit extract were mixed and incubated for $10 \mathrm{~min}$. The absorbance at $734 \mathrm{~nm}$ was then determined. The results were expressed in $\mathrm{mmol} \mathrm{TE} / \mathrm{kg}$ fw.

The total monomeric anthocyanins (TMA) were estimated by a $\mathrm{pH}$ differential method (GIUSTI; WROLSTAD, 2005) using a UV-VIS spectrophotometer (Model T60U, PG Instruments, USA). Absorbance was measured at 533 and 700 $\mathrm{nm}$ in buffers at $\mathrm{pH} 1.0$ and 4.5 using $\mathrm{pH} 4.5$ with a molar extinction coefficient of 29.600. Results were expressed as $\mu \mathrm{g}$ cyanidin-3-galactoside/g fw equivalent in $\mathrm{g}$ fresh weigh basis.

\section{Physico-mechanical properties}

To determine the size and mass of $\mathrm{cv}$. Braeburn apple, 25 fruits from every replication were randomly selected. The fruit length, width, and thickness were measured with $0.01 \mathrm{~mm}$ sensitive digital calipers (Model No; CD-6CSX, Mitutoyo, Japan). These dimensions were used to calculate the geometric mean diameter of apple fruits were determined methods presented by Mohsenin (1970). The fruit mass of the apples was measured with a digital electronic balance (Radvag PS 4500/C/1, Radom, Poland) with a resolution of $0.01 \mathrm{~g}$.

To determine flesh and skin firmness, 20 fruits from every replication were randomly selected. The flesh firmness was determined by puncturing on flesh surface of each apple fruit, by cutting apple skin, using an Effegi penetrometer (model FT-327; McCormick Fruit Tech, Yakima, WA) mounted on a hand-operated press, to minimize loading rate variations associated with the operator, and fitted with an $11.1 \mathrm{~mm}$ diameter plunger. Skin firmness was measured directly from the apple skin. Measurements were taken at three equatorial positions on each fruit at $120^{\circ}$ and the results were expressed in newtons $(\mathrm{N})$.

The skin thickness was determined by using a digital micrometer $(0-25 \mathrm{~mm}$, Insize, Austria) with an accuracy of $0.001 \mathrm{~mm}$. Skin thickness was measured on skin obtained sun exposed side of apple.

The fruit removal forces (FRF) were measured along longitudinal orientation stalk of twenty apple fruits for each treatment with a hand digital force gauge (Tronic, HF-10, Digital Dynamometer, 100 $\mathrm{N}$, Taiwan).

\section{Colour characteristics}

To determine of colour characteristics, the skin and flesh colours of twenty apples for every replication were measured using a colorimeter (Minolta, model CR-400, Tokyo, Japan). Chromatic analyses were conducted in accordance with the CIE (Commission Internationale de l'Eclairage) system of 1976. Values of $L^{*}, a^{*}$ and $b^{*}$ were used to define a three-dimensional colour space and interpreted as follows: $L^{*}$ indicates lightness, with values ranging from 0 (completely opaque or 'black') to 100 (completely transparent or 'white'); positive $a^{*}$ value indicates redness on the hue circle $\left(a^{*}=\right.$ greenness $)$ and a positive $b^{*}$ value indicates yellowness ( $b^{*}=$ blueness $)$. The colour measurements of apple samples were computed as the means of each treatment. The hue angle $\left(h^{\circ}\right)$, calculated as $h^{\circ}=\tan ^{-1} \mathrm{x} \mathrm{b}^{*} / \mathrm{a}^{*}$, expresses the colour nuance and values are defined as follows: red-purple: $0^{\circ}$; yellow: $90^{\circ}$; bluish-green: $180^{\circ}$; blue: $270^{\circ}$. The chroma $\left(C^{*}\right)$, obtained as $\mathrm{C}^{*}=\left(\mathrm{a}^{* 2}+\mathrm{b}^{* 2}\right)^{1 / 2}$, is a measure of chromaticity, which defines the purity or saturation of the colour (MCGUIRE, 1992). 


\section{Statistical analysis}

Experiments were performed using randomized complete-block design. All statistical analyses were performed with SAS version 9.3 (SAS Institute Inc., Cary, NC, USA). Data were analysed by means of analyze of variance. Main effects and interactions were analysed and means were compared by Duncan's multiple range test at a significance level of 0.05 .

\section{Results}

\section{Biochemical properties}

It was determined in our study that the increasing doses of AVG decreased TSS, $\mathrm{pH}$, starch index of apple, and increased TA (Table 1). The lowest and highest $\mathrm{pH}$ and TSS values were obtained from AVG-3 as $2.69-13.6 \%$ and AVG-0 dose as $2.87-15.44 \%$, respectively. The effect of the AVG treatment on TSS, pH, TA and starch index of apple were statistically significant $(\mathrm{p}<0.05)$.

The total phenolics (TP) decreased for flesh and skin of apples with increasing AVG doses (Table 1). While the lowest TP for flesh and skin apple was obtained from AVG-3 (650.4-5690.9 GAE/g fw respectively), the highest TP was obtained from AVG-0 treatment (1050.3-9656.5 GAE/g fw respectively). The effect of AVG treatments on TP of apple was statistically significant $(\mathrm{p}<0.05)$.

Table 1. Biochemical properties of cv. Braeburn apple as affected by AVG treatments.

\begin{tabular}{|c|c|c|c|c|}
\hline \multirow{2}{*}{ Chemical properties } & \multicolumn{4}{|c|}{ AVG treatments } \\
\hline & AVG-0 & AVG-1 & AVG-2 & AVG-3 \\
\hline TSS $(\%)$ & $15.44 \pm 0.14 \mathrm{a}$ & $14.36 \pm 0.14 \mathrm{~b}$ & $14.00 \pm 0.56 \mathrm{bc}$ & $13.60 \pm 0.10 \mathrm{c}$ \\
\hline $\mathrm{pH}$ & $2.87 \pm 0.05 \mathrm{a}$ & $2.85 \pm 0.04 \mathrm{a}$ & $2.80 \pm 0.03 \mathrm{a}$ & $2.69 \pm 0.08 \mathrm{~b}$ \\
\hline TA (g malic acid $100 \mathrm{~mL}^{-1}$ ) & $0.86 \pm 0.01 \mathrm{~b}$ & $0.88 \pm 0.05 \mathrm{ab}$ & $0.92 \pm 0.04 \mathrm{ab}$ & $0.93 \pm 0.02 \mathrm{a}$ \\
\hline Starch index & $6.0 \pm 0.50 \mathrm{a}$ & $5.0 \pm 0.76 \mathrm{ab}$ & $4.0 \pm 0.29 \mathrm{bc}$ & $4.0 \pm 0.58 \mathrm{c}$ \\
\hline \multicolumn{5}{|l|}{ Total phenolic $(\mu g$ GAE/gfw) } \\
\hline Flesh fruit & $1050.3 \pm 157.1 \mathrm{a}$ & $797.6 \pm 116.3 b$ & $772.6 \pm 178.0 \mathrm{~b}$ & $650.4 \pm 42.9 \mathrm{~b}$ \\
\hline Skin fruit & $9656.5 \pm 1685.9 \mathrm{a}$ & $7720.81 \pm 598.5 b$ & $7657.0 \pm 502.4 \mathrm{~b}$ & $5690.9 \pm 564.0 \mathrm{c}$ \\
\hline \multicolumn{5}{|c|}{ Total antioxidant activity $(\mu \mathrm{mol} T E / g$ fw) } \\
\hline \multicolumn{5}{|l|}{$\underline{\text { FRAP }}$} \\
\hline$\overline{\text { Flesh fruit }}$ & $0.81 \pm 0.04 \mathrm{a}$ & $0.81 \pm 0.03 \mathrm{a}$ & $0.77 \pm 0.07 \mathrm{a}$ & $0.75 \pm 0.03 \mathrm{a}$ \\
\hline Skin fruit & $5.94 \pm 0.46 \mathrm{a}$ & $5.69 \pm 0.08 \mathrm{a}$ & $5.59 \pm 0.44 \mathrm{a}$ & $4.66 \pm 0.50 \mathrm{~b}$ \\
\hline \multicolumn{5}{|l|}{$\underline{\text { TEAC }}$} \\
\hline Flesh fruit & $0.93 \pm 0.03 \mathrm{a}$ & $0.78 \pm 0.11 \mathrm{~b}$ & $0.72 \pm 0.03 \mathrm{~b}$ & $0.71 \pm 0.03 \mathrm{~b}$ \\
\hline Skin fruit & $8.17 \pm 0.77 \mathrm{a}$ & $6.30 \pm 0.24 \mathrm{~b}$ & $5.39 \pm 0.36 \mathrm{c}$ & $4.23 \pm 0.19 \mathrm{~d}$ \\
\hline \multicolumn{5}{|c|}{ Total monomeric anthocyanin ( $\mu$ g cyanidin-3-galactoside/g fw) } \\
\hline & $360.9 \pm 31.7 \mathrm{a}$ & $225.2 \pm 19.8 \mathrm{~b}$ & $147.3 \pm 12.9 \mathrm{c}$ & $112.6 \pm 9.9 \mathrm{c}$ \\
\hline
\end{tabular}

The difference between mean values shown on the same line with same lower letter is not significant $(\mathrm{P}<0.05)$.

Means of three replicates \pm standard deviation.

Source: Elaboration of the authors.

The total antioxidant activity (TAA) for flesh apple was higher in AVG-0 treatment as 0.81 and $0.93 \mu \mathrm{mol} \mathrm{TE} / \mathrm{g}$ fw (for FRAP and TEAC test) than those of the other treatments, respectively (Table 1). For apple skin, while the lowest TAA (for FRAP and
TEAC test) was obtained from AVG-3 treatment as 4.66 and $4.23 \mu \mathrm{mol} \mathrm{TE} / \mathrm{g}$ fw, the highest TAA was obtained from AVG-0 treatment as 5.94 and 8.17 $\mu$ mol TE/g fw, respectively. The effect of AVG treatment on TAA (FRAP and TEAC) for skin apple 
was statistically significant $(\mathrm{p}<0.05)$. In addition the effect of AVG on TAA of flesh apple for TEAC test was statistically significant $(\mathrm{P}<0.05)$.

The total monomeric anthocyanin (TMA) generally decreased in magnitude with an increase in AVG doses. The lowest and highest TMA values were obtained from AVG-3 as $112.6 \mu \mathrm{g}$ cy-3galactoside/g fw and AVG-0 as $360.9 \mu \mathrm{g}$ cy-3galactoside/g fw, respectively.

\section{Physico-mechanical properties}

The geometric mean diameter and fruit mass of apple were as $69.04 \mathrm{~mm}$ and $186.77 \mathrm{~g}$ (AVG-0); $69.44 \mathrm{~mm}$ and $188.53 \mathrm{~g}$ (AVG-1); $70.40 \mathrm{~mm}$ and $191.03 \mathrm{~g}$ (AVG-2); $71.27 \mathrm{~mm}$ and $197.53 \mathrm{~g}$ (AVG3 ), respectively (Table 2).

Table 2. Physico-mechanical properties of cv. Braeburn apple.

\begin{tabular}{lrrrr}
\hline Physico-mechanical & \multicolumn{4}{c}{ AVG treatments } \\
\cline { 2 - 5 } properties & \multicolumn{1}{c}{ AVG-0 } & \multicolumn{1}{c}{ AVG-1 } & \multicolumn{1}{c}{ AVG-2 } & \multicolumn{1}{c}{ AVG-3 } \\
\hline Geometric mean diameter, mm & $69.04 \pm 2.48 \mathrm{a}$ & $69.44 \pm 0.96 \mathrm{a}$ & $70.40 \pm 2.11 \mathrm{a}$ & $71.27 \pm 0.75 \mathrm{a}$ \\
Fruit mass, g & $186.77 \pm 8.50 \mathrm{a}$ & $188.53 \pm 7.39 \mathrm{a}$ & $191.03 \pm 4.03 \mathrm{a}$ & $197.53 \pm 8.32 \mathrm{a}$ \\
Flesh firmness, N & $84.78 \pm 3.84 \mathrm{~b}$ & $90.20 \pm 3.92 \mathrm{ab}$ & $91.39 \pm 3.42 \mathrm{ab}$ & $92.51 \pm 3.71 \mathrm{a}$ \\
Skin firmness, N & $106.14 \pm 4.58 \mathrm{~b}$ & $108.07 \pm 4.60 \mathrm{~b}$ & $109.22 \pm 0.23 \mathrm{~b}$ & $115.07 \pm 1.28 \mathrm{a}$ \\
Fruit removal force, N & $13.85 \pm 0.96 \mathrm{~b}$ & $15.82 \pm 1.13 \mathrm{~b}$ & $24.07 \pm 1.81 \mathrm{a}$ & $26.14 \pm 1.54 \mathrm{a}$ \\
Skin thickness, mm & $1.06 \pm 0.11 \mathrm{a}$ & $1.09 \pm 0.04 \mathrm{a}$ & $1.13 \pm 0.05 \mathrm{a}$ & $1.25 \pm 0.18 \mathrm{a}$ \\
\hline
\end{tabular}

The difference between mean values shown on the same line with same lower letter is not significant $(\mathrm{P}<0.05)$. Means of three replicates \pm standard deviation.

Source: Elaboration of the authors.

The effect of the AVG treatment on the geometric mean diameter, fruit mass and skin thickness of apple were not statistically significant, whereas, the flesh and skin firmness was statistically significant $(\mathrm{p}<0.05)$. The flesh and skin firmnesses of $\mathrm{cv}$. Braeburn apple increased from 84.78 to $92.51 \mathrm{~N}$ and from 106.14 to $115.07 \mathrm{~N}$ with increasing from AVG-0 to AVG-3. Both flesh firmness and skin firmness were higher in the other AVG doses treated apples as compared to AVG-0 dose. The fruit removal force values increased from 13.85 to $26.14 \mathrm{~N}$ with an increase in AVG dose from 0 to
$500 \mathrm{mg} \mathrm{L} \mathrm{L}^{-1}$. The all physico-mechanical properties linearly increased with increasing of AVG doses (Table 2).

\section{Colour characteristics}

The results indicate that color parameters of skin apple were not a statistical difference between the AVG treatments. The $L^{*}, \mathrm{C}^{*}$ and $h^{\circ}$ values of apple skin were 53.08, 41.66 and 57.58 (AVG-0); 54.29, 40.57 and 59.45 (AVG-1); 53.95, 40.42 and 58.48 (AVG-2); 54.89, 41.17 and 59.29 (AVG-3), respectively. 
Table 3. The effect of AVG treatments on colour characteristics of cv. Braeburn apple.

\begin{tabular}{|c|c|c|c|c|}
\hline \multirow{2}{*}{$\begin{array}{l}\text { Colour } \\
\text { characteristics }\end{array}$} & \multicolumn{4}{|c|}{ AVG treatments } \\
\hline & AVG-0 & AVG-1 & AVG-2 & AVG-3 \\
\hline \multicolumn{5}{|l|}{ Skin colour } \\
\hline$L^{*}$ & $53.08 \pm 1.09 \mathrm{a}$ & $54.29 \pm 0.72 \mathrm{a}$ & $53.95 \pm 1.71 \mathrm{a}$ & $54.89 \pm 2.51 \mathrm{a}$ \\
\hline$C^{*}$ & $41.66 \pm 0.77 \mathrm{a}$ & $40.57 \pm 0.62 \mathrm{a}$ & $40.42 \pm 0.46 \mathrm{a}$ & $41.17 \pm 0.88 \mathrm{a}$ \\
\hline$h^{\circ}$ & $57.58 \pm 4.27 \mathrm{a}$ & $59.45 \pm 2.29 \mathrm{a}$ & $58.48 \pm 0.56 \mathrm{a}$ & $59.29 \pm 3.88 \mathrm{a}$ \\
\hline \multicolumn{5}{|l|}{ Flesh colour } \\
\hline$L^{*}$ & $82.36 \pm 0.68 \mathrm{a}$ & $81.67 \pm 0.76 b$ & $80.72 \pm 0.18 \mathrm{ab}$ & $81.48 \pm 0.32 \mathrm{ab}$ \\
\hline$C^{*}$ & $39.25 \pm 2.48 \mathrm{a}$ & $35.99 \pm 0.33 \mathrm{a}$ & $37.74 \pm 0.63 \mathrm{a}$ & $38.30 \pm 3.68 \mathrm{a}$ \\
\hline$h^{\circ}$ & $94.72 \pm 1.84 \mathrm{~b}$ & $98.43 \pm 1.58 \mathrm{ab}$ & $96.51 \pm 1.48 \mathrm{ab}$ & $96.63 \pm 0.71 \mathrm{ab}$ \\
\hline
\end{tabular}

The difference between mean values shown on the same line with same lower letter is not significant $(\mathrm{P}<0.05)$.

Means of three replicates \pm standard deviation.

Source: Elaboration of the authors.

The colour characteristics for skin apple generally increased in magnitude with an increase in AVG doses. Hue angle values for both skin and flesh apple fruits increased as AVG doses increased from $0 \mathrm{mg} \mathrm{L}^{-1}$ to $500 \mathrm{mg} \mathrm{L}^{-1}$, respectively (Table 3).

\section{Discussion and Conclusions}

AVG treatments at preharvest delay the maturity of fruit on optimal harvest date (GREENE, 2005). As maturity of fruit increases, TSS and $\mathrm{pH}$ increases as well (TURK; KOCAK; AKBUDAK, 1995). Amarante et al. (2002) reported that total soluble solids content, titratable acidity and starch index were delayed by AVG.

These results indicate that the antioxidant and phenolic are present in the flesh and skin, which are in agreement with previous works (DROGOUDI; MICHAILIDIS; PANTELIDIS, 2008; VIEIRA et al., 2009). Also, several authors (WU et al., 2004; HALVORSEN et al., 2006) have determined that skin apple had a higher antioxidant capacity than the flesh apple. Different researches (CHINNICI et al., 2004; DROGOUDI; MICHAILIDIS; PANTELIDIS, 2008) have reported that the antioxidant activitiy of skin apple were two to nine times greater than flesh apple. In addition, Whale et al. (2008) reported that AVG negatively affected the concentration of flavanoids and anthocyanin. Awad and Jager (2002) reported that flavanol and phenolics concentration in Jonagold apples were not affected by AVG tretments. Wojdylo, Oszmian and Laskowsk1 (2008) reported that the total antioxidant activity was found as $23.4,29.7,23.2,26.4 \mu \mathrm{M} / \mathrm{g}$ aaccording to FRAP test respectively.

The physico-mechanical properties of apple were affected by AVG doses. The sizes and mass of fruit were affected by dependent of plant growth regulator doses (LAWES; WOOLLEY, 2001; GREENE; SCHUPP, 2004; GREENE, 2006). Amarante et al. (2002) reported that as AVG treated, there were increases in flesh firmness, skin firmness, and fruit size value. Byers (1997) reported that AVG increased flesh firmness of fruit, especially if they were harvested after the optimal harvest date. Yuan and $\mathrm{Li}$ (2008) reported that flesh firmness of apple fruit was $75.2 \mathrm{~N}$ with the AVG application $\left(125 \mathrm{mgL}^{-}\right.$ $\left.{ }^{1}\right)$. Tabatabaeefar and Rajabipour (2005) reported that the geometric mean diameter of Redspar and Delbarstival apples were $79.54 \mathrm{~mm}$ and 63.38 $\mathrm{mm}$ for Redspar and Delbarstival, respectively. Gezer, Guner and Dursun (2000) reported that fruit removal force for Golden Delicious was as 16.57 N. Sahin (2007) reported that fruit-removal-force of apples was $14.57 \mathrm{~N}$ ('Golden Delicious') and 9.86 N (Starking Delicious). Our findings show similarity with those reported by researchers. 
The colour characteristics affects the market value of fruit depending on fruit quality. AVG delays maturity in fruits (AMARANTE et al., 2002; GREENE, 2005). In addition, AVG slows down coloration as well as delaying fruit maturation (RATH; PRENTICE, 2004). However, it indirectly increases coloration as it prolongs fruit life on tree (KIM et al., 2004; GREENE, 2005). Greene and Schupp (2004) reported that AVG applications delayed the red color development in fruits.

The effect of AVG treatment on total soluble solids content, titratable acidity, $\mathrm{pH}$ and starch index of apple fruits was statisticaly significant. Increasing concentrations of AVG decreased TSS, $\mathrm{pH}$ and starch index and increased TA. The effects of AVG treatment on total phenolic and total antioxidant activity (for TEAC test) were significant for both flesh and skin of apple. The total phenolic and total antioxidant activity were higher in the skin fruit than flesh fruit. The total monomeric anthocyanin generally decreased in magnitude with an increased AVG doses.

The all physico-mechanical properties were higher in AVG-3 treatment than those of the other treatments. The effect of the AVG treatment on the fruit removal force, flesh and skin firmness were statistically significant. The colour characteristics $\left(L^{*}, C^{*}, h^{\circ}\right)$ for skin apple were not statistically significant.

\section{Acknowledgements}

The chemicals (AVG: ReTain ${ }^{\circledR}$ and Surfactant: Sylgard 309) used in this study were provided by ValentBioscience and Dow Corning Corp., respectively.

\section{References}

AMARANTE, C. V.T. D.; SIMIONI, A.; MEGGUER, C. A.; BLUM, L. E. B. Effect of amınoethoxyvinilglycine (AVG) on preharvest fruit drop and maturity of apples. Revista Brasileira de Fruticultura, Cruz das Almas, v. 24, n. 3, p. 661-664, 2002.
ANONYMOUS. Turkish state meteorological service. Regional Directorate of Tokat. Tokat, 2011.

AWAD, M. A.; JAGER, A. Formation of flavanoids, especially anthocyanin and chlorogenic acid in Jonagold apple skin: Influences of growth regulators and fruit maturity. Scientia Horticulturae, Amsterdam, v. 93, n. 3-4, p. 257-266, 2002.

BANGERTH, F. The effect of a substituted amino acid on ethylene biosynthesis, respiration, ripening and preharvest drop of apple fruits. Journal of the American Society for Horticultural Science, Alexandria, v. 103, n. 3, p. 401-404, 1978.

BENZIE, I. F. F.; STRAIN, J. J. The ferric reducing ability of plasma (FRAP) as a measure of "antioxidant power": the FRAP assay. Analyitical Biochemistry, San Diego, v. 239, n. 1, p. 70-76, 1996.

BLANPIED, W. J.; SILSBY, K. J. Predicting harvest date Windows for apples. Cornell Cooperative Extension and Information Bulletin, New York, v. 221, n. 1, p. 1-18, 1992.

BOYER, J.; LIU, R. H. Apple phytochemicals and their health benefits. Nutriton Journal, London, v. 3, n. 5, p. 1-15, 2004.

BRAMLAGE, W. J.; GREENE, D. W.; AUTIO, W. R.; MCLAUGHLIN, J. M. Effects of Aminoethoxyvinylglycine on internal ethylene concentrations and storage of apples. Journal of the American Society for Horticultural Science, Alexandria, v. 105, n. 6, p. 847-851, 1980.

BYERS, R. E. Effects of aminoethoxyvinylglycine (AVG) on preharvest fruit drop and maturity of 'Delicious' apples. Journal of Tree Fruit Production, London, v. 2, n. 1, p. 53-75, 1997.

CHINNICI, F.; BENDINI, A.; GAIANI, A.; RIPONI, C. Radical scavenging activities of peels and pulps from cv. golden delicious apples as related to their phenolic composition. Journal of Agricultural Food Chemistry, Washington: ACS, v. 52, p. 4684-4689, 2004.

DROGOUDI, P.; MICHAILIDIS, Z.; PANTELIDIS, G. Peel and flesh antioxidant content and harvest quality characteristics of seven apple cultivars. Scientia Horticulturae, Amsterdam, v. 115, n. 2, p. 149-153, 2008.

FAN, X.; MATTHEIS, J. P.; FELLMAN, J. K. C.; PATTERSON, M. E. Changes in jasmonic acid concentration during early development of apple fruit. Physiologia Plantarum, Hoboken, v. 101, n. 2, p. 328332, 1997. 
GEZER, I.; GUNER, M.; DURSUN, E. Determination of physical and mechanical properties of some fruits and vegetables. Turk-Koop. Ekin Journal, Ankara, v. 13, n. 1, p. 70-73, 2000. (in Turkish).

GIUSTI, M. M.; WROLSTAD, R. E. Characterization and measurement of anthocyanins by UV-visible spectroscopy Unit F1.2. In: WROLSTAD, R. E.; SCHWARTZ, S. J. (Ed.). Handbook of food analytical chemistry. Wiley, New York, 2005. p. 19-31.

GREENE, D. W. An update on preharvest drop control of apples with Aminoethoxyvinylglycine (ReTain). Acta Horticulturae, Leuven, v. 727, n. 1, p. 311-319, 2006.

GREENE, D. W. Time of Aminoethoxyvinylglycine influences preharvest drop and quality of 'McIntosh' apples. Hortscience, Alexandria, v. 40, n. 7, p. 20562060, 2005.

GREENE, D. W.; SCHUPP, J. R. Effect of aminoethoxyvinylglycine (AVG) on preharvest drop, fruit quality, and maturation of 'McIntosh' apples. II. Effect of timing and concentration relationships and spray volume. Hortscience, Alexandria, v. 39, n. 5, p. 1036-1041, 2004.

HALVORSEN, B.; CARLSEN, M.; PHILLIPS, K.; BOHN, S.; HOLTE, K.; JACOBS, D.; BLOMHOFF, R. Content of redox-active compounds (i.e., antioxidants) in foods consumed in the United States. The American Journal of Clinical Nutrition, Maryland, v. 84, n. 1, p. 95-135, 2006.

KIM, I. S.; CHOI, C. D.; LEE, H. J.; BYUN, J. K. Effect of Aminoethoxyvinylglycine on preharvest drop, fruit quality of Mibaekdo peaches. In: KANG, S. M. (Ed.). Acta Horticulturae, Leuven, v. 653, n. 1, p. 173-178, 2004.

LATA, B. Relationship between apple peel and the whole fruit antioxidant content: Year and cultivar variation. Journal of Agricultural Food Chemistry, Washington, v. 55, n. 3, p. 663-671, 2007.

LATTANZIO, V. Bioactive polyphenols: their role in quality and storability of fruit and vegetables. Journal of Applied Botany and Food Quality, Quedlinburg, v. 77, n. 5-6, p. 128-146, 2003.

LAWES, G. S.; WOOLLEY, D. J. The commercial use of plant growth regulators to regulate fruit development. Acta Horticulturae, Leuven, v. 553, n. 1, p. 149-150, 2001.
MARI, A.; TEDESCO, I.; NAPPO, A.; RUSSO, G. L.; MALORNI, A.; CARBONE, V. Phenolic compound characterisation and antiproliferative activity of "Annurca" apple, a southern Italian cultivar. Food Chemistry, Reading, v. 123, n. 1, p. 157-164, 2010.

MCGUIRE, R. G. Reporting of objective colour measurements. Hortscience, Alexandria, v. 27, n. 12, p. 1254-1255, 1992.

MOHSENIN, N. N. Physical properties of plant and animal materials. New York: Gordon and Breach Science Publication, 1970.

OZGEN, M.; REESE, R. N.; TULIO, A. Z.; MILLER, A. R.; SCHEERENS, J. C. Modified 2,2- azino-bis-3ethylbenzothiazoline-6-sulfonic acid (ABTS) method to measure antioxidant capacity of selected small fruits and comparison to ferric reducing antioxidant power (FRAP) and 2,20-diphenyl-1-picrylhydrazyl (DPPH) methods. Journal of Agricultural Food Chemistry, Washington, v. 54, n. 4, p. 1151-1157, 2006.

RATH, A. C.; PRENTICE, A. J. Yield increase and higher flesh firmness of 'Arctic Snow' nectaries both at harvest in Australia and after export to Taiwan following pre-harvest application of ReTain plant growth regulator (aminoethoxyvinylglycine, AVG). Australian Journal of Experimental Agriculture, Victoria, v. 44, n. 3, p. 343351, 2004.

SAHIN, F. Determination of physical and mechanical properties of apple for harvest handling. 2007. Ms. Thesis (Biological materials) - Gaziosmanpasa University, Graduate School of Natural and Applied Science. Department of Agricultural Machines TokatTurkey, in Turkish.

SINGLETON, V. L.; ROSSI, J. L. Colorimetry of total phenolics with phosphomolybdic- phosphotungstic acid reagents. American Journal of Enology and Viticulture, Davis, v. 16, n. 3, p. 144-158, 1965.

STURM, K.; HUDINA, M.; SOLAR, A.; VIRSCEKMARN, M.; STAMPAR, F. Fruit quality of different 'Gala' clones. Gartenbauwissenschaften, v. 68, n. 4, p. 169-175, 2003.

TABATABAEEFAR, A.; RAJABİOUR, A. Modeling the mass of apples by geometrical attributes. Scientia Horticulturae, Amsterdam, v. 105, n. 3, p. 373-382, 2005.

TREUTTER, D. Biosynthesis of phenolic compounds and its regulation in apple. Plant Growth Regulation, Dordrecht, v. 34, n. 1, p. 71-89, 2001. 
TSAO, R.; YANG, R.; XIE, S.; SOCKOVIE, E.; KHANIZADEH, S. Which polyphenolic compounds contribute to the total antioxidant activities of apple. Journal of Agricultural Food Chemistry, Washington, v. 53, n. 12, p. 4989-4995, 2005.

TURK, R.; KOCAK, K.; AKBUDAK, B. The effect of modified atmosphere on storage period in plums. In: NATIONAL HORTICULTURE CONGRESS, 2., 1995, Adana, Turkey. Proceedings... Adana, Turkey, 1995. p. 203-208.

VIEIRA, F.; BORGES, G.; COPETTI, C.; AMBONI, R.; DENARDI, F.; FETT, R. Physico-chemical and antioxidant properties of six apple cultivars (Malus domestica Borkh.) grown in southern Brazil. Scientia Horticulturae, Amsterdam, v. 122, n. 3, p. 421-425, 2009.

WANG, Z.; DILLEY, D. R. Aminoethoxyvinylglycine, combined with ethephon, can enhance red color development without over-ripening apples. Hortscience, Alexandria, v. 36, n. 2, p. 328-331, 2001.

WHALE, S. K.; SINGH, Z.; BEHBOUDIAN, M. H.; JANES, J.; DHALIWAL, S. S. Fruit quality in 'Cripp's Pink' apple, especially colour, as affected by preharvest sprays of aminoethoxyvinylglycine and ethephon. Scientia Horticulturae, Amsterdam, v. 115, n. 4, p. 342351, 2008.
WILLIAMS, M. W. Retention of fruit firmness and increase in vegetative growth and fruit set of apples with aminoethoxyvinylglycine. Hortscience, Alexandria, v. 15, n. 1, p. 76-77, 1980.

WOJDYLO, A.; OSZMIAN, S. J.; LASKOWSKI, P. Polyphenolic compounds and antioxidant activity of new and old apple varieties. Journal of Agricultural Food Chemistry, Washington, v. 56, n. 15, p. 6520-6530, 2008.

WOLFE, K.; WU, X.; LIU, R. H. Antioxidant activity of apple peels. Journal of Agricultural Food Chemistry, Washington, v. 51, n. 3, p. 609-614, 2003.

WU, X.; BEECHER, G.; HOLDEN, J.; HAYTOWITZ, D.; GEBHARDT, S.; PRIOR, R. Lipophilic and hydrophilic antioxidant capacities of common foods in United States. Journal of Agricultural Food Chemistry, Washington, v. 52, n. 12, p. 4026-4037, 2004.

YUAN, R.; LI, J. Effect of sprayable 1-MCP, AVG, and NAA on ethylene biosynthesis, preharvest drop, fruit maturity, and quality of 'Delicious' apples. Hortscience, Alexandria, v. 43, n. 5, p. 1454-1460, 2008. 